\section{Pengunaan Model Pembelajaran Kooperatif Tipe Tebak Kata dalam Keterampilan Berbicara Bahasa Jerman Siswa}

\author{
Murniati' ${ }^{1}$, Muddin'2 dan Burhanuddin ${ }^{3}$ \\ Fakultas Bahasa dan Sastra \\ Universitas Negeri Makassar \\ Email: murniati@gmail.com ${ }^{1}$ \\ http://ojs.unm.ac.id/index.php/Insani/index
}

\begin{abstract}
Abstrak. Tujuan penelitian ini adalah untuk memeroleh data tentang keefektifan model pembelajaran kooperatif tipe tebak kata dalam keterampilan berbicara bahasa Jerman siswa. Penelitian ini adalah penelitian eksperimen semu. Populasi penelitian ini adalah seluruh siswa kelas XI SMA Semen Tonasa yang terdiri dari 2 kelas yang berjumlah 97 orang siswa. Sampel yang digunakan adalah Random Sampling, yaitu siswa kelas XI IPS 2 yang berjumlah 28 siswa sebagai kelas eksperimen dan siswa kelas XI IPS I yang berjumlah 28 siswa sebagai kelas kontrol. Data yang diperoleh dianalisis dengan menggunakan rumus uji-t. Hasil analisis data menunjukan (thitung3,34>t tabel2,005 pada taraf signifikan a 0,05. Hasil penelitian menunjukkan bahwa model pembelajaran kooperatif tipe tebak kata efektif dalam keterampilan berbicara bahasa Jerman siswa.
\end{abstract}

Kata Kunci : Keefektifan, Model Kooperatif, Tipe Tebak Kata.

\section{INDONESIAN JOURNAL OF EDUCATIONAL STUDIES (IJES)}

\section{E-ISSN: 2621-6744 P-ISSN: 2621-6736}

Submitted: May $14^{\text {th }} 2018$

Accepted : June $26^{\text {th }} 2018$

Abstract. The purpose of this study was to obtain data on the effectiveness of cooperative learning models guessing words in students' speaking skills. This research is a quasi-experimental study. The population of this study was all students of class XI Semen Tonasa High School consisting of 2 classes totaling 97 students. The sample used was Random Sampling, namely students of class XI IPS 2, amounting to 28 students as the experimental class and students of class XI IPS I, amounting to 28 students as the control class. The data obtained were analyzed using the t-test formula. The results of data analysis showed ( $t$ count 3.34> $t$ table 0.005 at a significant level of $\alpha 0.05$. The results showed that the cooperative learning model guessed the word effective in the German speaking skills of students. 


\section{PENDAHULUAN}

Bahasa merupakan satu dari berbagai unsur penting yang diperlukan dalam kehidupan manusia sebagai makhluk sosial. Fungsi bahasa adalah sebagai alat untuk berkomunikasi, dalam kegiatan berkomunikasi manusia menyampaikan hal-hal yang menjadi tujuan atau ungkapan hatinya. Penguasaan satu atau dua bahasa saja tidaklah cukup untuk menyikapi kemajuan dunia, apalagi bahasa yang dikuasai hanyalah bahasa daerah atau bahasa nasioanl saja. Menyikapi hal tersebut, maka penguasaan bahasa asing adalah suatu kebutuhan agar turut mendukung berbagai aspek yang dimiliki negara Indonesia sebagai negara berkembang. Bahasa asing merupakan alat komunikasi antarmanusia yang memudahkan manusia untuk dapat berinteraksi dengan orang lain di seluruh belahan dunia. Komunikasi tersebut merupakan sarana untuk mencapai tujuan ekonomi, sosial budaya, dan pendidikan. Kebutuhan akan bahasa asing termasuk bahasa Jerman saat ini telah menjadi hal yang tidak perlu dipertanyakan lagi bahkan tidak sedikit sekolah yang menjadikan bahasa Jerman sebagai bahasa asing kedua yang wajib dipelajari setelah bahasa Inggris.

Pembelajaran bahasa Jerman memiliki empat kompetensi berbahasa yang harus dipelajari siswa yaitu: menyimak (hören), membaca (lesen), berbicara (sprechen) dan menulis (schreiben). Pada dasarnya dalam pembelajaran bahasa, keempat keterampilan tersebut saling terintegrasi dan tidak dapat dipisahkan. Selain itu, Strukturen und Wortschatz (tata bahasa dan kosakata) diajarkan secara terpadu sebagai penunjang dalam keempat keterampilan tersebut. Keterampilan berbicara merupakan salah satu dari keempat keterampilan berbahasa Jerman yang penting untuk dikembangkan. Sebagaimana diungkapkan dalam Kurikulum KTSP 2006, kompetensi dasar dalam pembelajaran keterampilan berbicara bahasa Jerman siswa kelas XI yaitu (1) menyampaikan informasi secara lisan dalam kalimat sederhana sesuai konteks yang mencerminkan kecakapan berbahasa yang santun dan tepat. (2) melakukan dialog sederhana dengan lancar yang mencerminkan kecakapan berkomunikasi dengan santun dan tepat.

Hasil observasi yang dilakukan peneliti di SMA Semen Tonasa pada tanggal 3 Februari 2018 menunjukkan bahwa di kelas XI kemampuan siswa dalam berbahasa Jerman khususnya pada keterampilan berbicara tergolong masih rendah, informasi ini diperkuat dengan adanya hasil ulangan semester ganjil kelas XI IPS 1 Tahun Ajaran 2015/2016 yang menunjukkan bahwa ada sekitar 64\% siswa yang memeroleh nilai 65 dan merupakan di bawah Standar Kriteria Ketuntasan Minimal (KKM), kemudian di kelas yang sama pada semester genap menunjukkan bahwa ada sekitar 68\% siswa yang memeroleh nilai di bawah 75 yang merupakan Standar Kriteria Ketuntasan Minimal (KKM), dan di kelas XI IPS 2 menunjukkan bahwa ada sekitar 71\% siswa yang memeroleh nilai di bawah Standar Kriteria Ketuntasan Minimal (KKM) yaitu 68. Hal ini dikarenakan keterampilan berbicara masih dianggap sulit oleh siswa karena baru pertama kali dipelajari. Di samping itu partisipasi siswa dalam pembelajaran berbicara di kelas cenderung pasif. Salah satu faktor penyebabnya yaitu kurang menarik dan bervariasinya model pembelajaran yang digunakan oleh guru. Model yang digunakan guru dalam mengajar masih terpaku pada metode konvensional, yaitu berupa ceramah, tanya jawab, dan media papan tulis. Meski ini juga merupakan kegiatan 
pembelajaran yang efektif, namun hal ini menjadikan proses pembelajaran bahasa terkesan menoton dan siswa cenderung mengalami kebosanan dalam mempelajari bahasa Jerman. Berdasarkan permasalahan tersebut, maka tujuan dari penelitian ini untuk mengetahui penggunaan model pembelajaran kooperatif tipe Tebak Kata efektif dalam meningkatkan keterampilan berbicara siswa kelas XI SMA Semen Tonasa Kabupaten Pangkep.

\section{MODEL KOOPERATIF TIPE TEBAK KATA}

Model Pembelajaran Kooperatif merupakan sebuah lingkungan belajar yang mengarahkan siswa untuk bekerja sama dalam sebuah kelompok kecil, selain itu siswa diberikan kesempatan berinteraksi secara aktif dalam kelompok belajarnya untuk mencapai tujuan pembelajaran. Suprijono (2015: 73) mengemukakan: "Pembelajaran Kooperatif adalah konsep yang lebih luas meliputi semua jenis kerja kelompok termasuk bentuk-bentuk yang lebih diarahkan oleh guru". Senada dengan Suprijono, Isjoni (2014: 15): menyatakan: "Cooperative Learning berasal dari kata cooperative yang artinya mengerjakan sesuatu secara bersama-sama dengan saling membantu satu sama lainnya sebagai satu kelompok atau satu tim". Hal yang sama dikemukakan oleh Solihatin,E dan Rahardjo dalam Taniredja, (2013: 56): "Cooperative Learning juga dapat diartikan sebagai suatu struktur tugas bersama dalam suasana kebersamaan di antara sesama anggota kelompok". Pendapat lain dikemukakan oleh Rusman (2014: 202): "Pembelajaran Kooperatif merupakan bentuk pembelajaran dengan cara siswa belajar dan bekerja dalam kelompok-kelompok kecil secara kolaboratif yang anggotanya terdiri dari empat sampai enam orang dengan struktur kelompok yang bersifat heterogen. Berdasarkan pendapat di atas, dapat disimpulkan bahwa model pembelajaran kooperatif merupakan salah satu lingkungan belajar yang dilakukan secara berkelompok yang anggotanya terdiri dari beberapa orang dengan struktur kelompok yang bersifat heterogen dengan tujuan saling membantu satu dengan yang lainnya untuk menyelesaikan sebuah tugas atau mencapai satu tujuan bersama.

Model pembelajaran kooperatif diciptakan untuk membuat proses pembelajaran terkesan tidak membosankan bagi para siswa dan model pembelajaran ini memiliki sangat banyak tipe seperti, Bertukar Pasangan, Word Square, Picture and Picture, Inside-Outside Circle, dan Tebak Kata. Menurut Kurniasih dan Sani (2016: 94): Model pembelajaran tipe Tebak Kata merupakan model pembelajaran yang menggunakan media kartu Teka-Teki yang berpasangan dengan kartu jawaban TekaTeki. Permainan Tebak Kata dilaksanakan dengan cara siswa menjodohkan kartu soal Teka-Teki dengan kartu jawaban yang tepat. Melalui permainan Tebak Kata, selain anak menjadi tertarik untuk belajar juga memudahkan dalam menanamkan konsep pelajaran. Menurut Said dalam Syamsiah dan Wedyawati (2017: 32): "Model kooperatif Tebak Kata adalah menebak suatu kata dengan cara menyebutkan katakata tertentu sampai kata yang disebutkan benar". Sementara itu Suprijono dalam Kurniasari, dkk (2009: 2) yang menyatakan: "Model Tebak Kata adalah suatu model pembelajaran dengan cara menebak hal apa yang dimaksud di dalam indikator yang ada di karton." Berdasarkan uraian tersebut, maka dapat disimpulkan bahwa model pembelajaran kooperatif tipe Tebak Kata merupakan salah satu tipe Cooperative Learning dengan menggunakan media kartu Teka-Teki yang berpasangan dengan 
kartu jawaban Teka-Teki, model ini lebih menekankan keaktifan siswa dengan cara menyebutkan kata-kata tertentu sampai kata yang disebutkan benar dan sesuai dengan indikator yang ada dalam kartu Teka-Teki.

Model ini dalam penerapannya memerlukan langkah-langkah agar proses penyajiannya dapat berjalan sebagaimana mestinya. Adapun langkah-langkah yang akan digunakan dalam penelitian ini yaitu modifikasi dari pendapat Kurniasih dan Sani (2016: 96) yaitu sebagai berikut: (1) guru menjelaskan aturan main dalam permainan ini. (2) guru membagi siswa menjadi beberapa pasang masing-masing pasangan terdiri 2 orang. (3) siswa berdiri secara berhadapan. Siswa yang satu memakai bando dengan kata di atasnya yang akan di tebak oleh siswa tersebut. (4) siswa lainnya bertugas menyebutkan ciri-ciri atau inisial terkait dengan kata yang terdapat pada bando yang dipakai pasangannya. Setiap model pembelajaran memiliki kelebihan dan kekurangan masing masing, begitupun dengan model pembelajaran tipe Tebak Kata. Adapun kelebihan dari model pembelajaran tipe Tebak Kata yang dikemukakan oleh Kurniasih dan Sani (2016: 95-96) mengungkapkan kelebihan model pembelajaran kooperatif tipe Tebak Kata yang pada intinya yaitu: “(1) anak akan mempunyai kekayaan bahasa, (2) sangat menarik sehingga setiap siswa ingin mencobanya, (3) Siswa menjadi tertarik untuk belajar, (4) Memudahkan dalam menanamkan konsep pelajaran dalam ingatan siswa."

Djumingin (2011: 187) mengemukakan tentang kelebihan dari model pembelajaran kooperatif tipe Tebak Kata yaitu "Metode ini sangat menarik sehingga siswa ingin mencobanya." Selain memiliki kelebihan, model pembelajaran kooperatif tipe Tebak Kata ini juga memiliki kekurangan yaitu: (1) Memerlukan waktu yang lama sehingga materi sulit tersampaikan; (2) bila siswa tidak menjawab dengan benar maka tidak semua siswa dapat maju karena waktu terbatas (Kurniasih dan Sani, 2016: 95-96). Senada dengan Kurniasih dan Sani, Djumingin (2011: 187) juga menyatakan tentang kekurangan model pembelajaran kooperatif tipe Tebak Kata tersebut yaitu : Bila siswa tidak menjawab dengan benar maka tidak semua siswa dapat maju karena waktu terbatas.

\section{METODE PENELITIAN}

Penelitian ini terdiri atas dua variabel. Variabel pertama pada penelitian ini adalah model Pembelajaran Kooperatif sebagai variabel bebas (X), sedangkan keterampilan berbicara bahasa Jerman sebagai variabel terikat ( $\mathrm{Y}$ ). Desain yang digunakan dalam penelitian ini yaitu Quasi Eksperimental dengan bentuk Nonequivalent Control Group Design. Dalam penelitian ini melibatkan dua kelompok yaitu kelas eksperimen yang menggunakan model Pembelajaran Kooperatif tipe Tebak Kata dan kelas kontrol menggunakan model pembelajaran konvensional dalam pembelajaran keterampilan berbicara bahasa Jerman siswa kelas XI SMA Semen Tonasa Kabupaten Pangkep. Variabel bebas $(X)$ yang dimaksud adalah penggunaan model pembelajaran kooperatif tipe Tebak Kata, sedangkan keterampilan berbicara bahasa Jerman siswa kelas XI SMA Semen Tonasa kabupaten pangkep sebagai variabel terikat $(\mathrm{Y})$.

Populasi dalam penelitian ini adalah seluruh siswa kelas XI SMA Semen Tonasa Kabupaten Pangkep yang terdiri dari 4 kelas, dengan jumlah siswa 97 orang. Sampel dalam penelitian ini menggunakan sampel acak (random sampling). Dari 4 kelas 
populasi dipilih dua kelas sebagai sampel. Dari hasil pemilihan secara acak terpilih siswa kelas XI IPS 2 yang berjumlah 28 siswa sebagai kelas eksperimen dan kelas XI IPS 1 yang berjumlah 28 siswa sebagai kelas kontrol. Teknik analisis data dalam penelitian ini menggunakan analisis statistika deskriptif dan inferensial untuk menguji hipotesis penelitian dengan menggunakan uji-t. Sebelum melakukan pengujian tersebut terlebih dahulu dilakukan uji normalitas dengan menggunakan tabel Z-score, chi kuadrat, dan uji homogenitas dengan menggunakan uji F (Fisher). Sebelum menentukan uji normalitas data dan homogenitas maupun uji hipotesis terlebih dahulu tentukan nilai rata-rata (mean), simpangan baku dan varian.

\section{HASIL DAN PEMBAHASAN}

Dalam penelitian ini, pre-test yang diberikan untuk mengetahui kemampuan awal siswa dalam keterampilan berbicara bahasa Jerman siswa menunjukkan bahwa kelas eksperimen (XI IPS 2) memeroleh nilai rata-rata (mean) sebesar 50,68 dengan hasil analisis menunjukkan bahwa 2 siswa (7\%) yang memeroleh nilai terendah yaitu 33 dan 5 siswa (18\%) memeroleh nilai tertinggi yaitu 67, sementara kelas kontrol (XI IPS 1) memeroleh nilai rata-rata (mean) sebesar 52,72 dengan hasil analisis menunjukkan bahwa 3 siswa (11\%) memeroleh nilai terendah yaitu 33 dan 7 siswa (25\%) memeroleh nilai tertinggi yaitu 67. Rendahnya perolehan nilai pada kedua kelas tersebut dikarenakan informasi yang disampaikan kurang komunikatif, beberapa kalimat yang diucapkan terdapat kesalahan, kosakata yang digunakan masih sangat kurang, serta masih banyak terdapat kesalahan pada pelafalan dan intonasi sehingga tidak dapat dimengerti. Hasil nilai pre-test tersebut kemudian di uji dengan menggunakan uji normalitas dan uji homogenitas. Uji normalitas dimaksudkan untuk mengetahui apakah kedua sampel yang diteliti berdistribusi normal atau tidak, sedangkan uji homogenistas dimaksudkan untuk mengetahui apakah kedua sampel dalam penelitian tersebut homogen atau tidak.

Hasil analisis uji normalitas menunjukkan bahwa harga yang diperoleh pada kelas eksperimen (XI IPS 2) dan kelas kontrol (XI IPS 1) masing-masing sebesar 157,05 dan -125,57. Hasil tersebut kemudian dibandingkan dengan tabel chi-kuadrat ( $d k=5$, taraf signinfikasi 0,05$)$ sebesar 11,07 menunjukkan bahwa $x^{2}$ hitung $<x^{2}$ tabel $(-$ $157,05<11,07)$ dan $(-125,57<11,07)$ begitupun data post-test yang diperoleh pada kedua kelas tersebut masing-masing sebesar-98,33dan-127,36. Hasil tersebut kemudian dikonsultasikan dengan tabel chi-kuadrat ( $\mathrm{dk}=5$, taraf signinfikasi 0,05$)$ sebesar 11,07 menunjukkan bahwa $x^{2}$ hitung < $x^{2}$ tabel $(-98,33<11,07)$ dan $(-127,36<$ 11,07), sehingga distribusi data pre-test dan post-test dinyatakan normal, artinya tes yang diberikan sesuai dengan kemampuan siswa. Adapun hasil uji homogenitas menunjukkan bahwa nilai $F_{\text {hitung }}$ pada kelas ekperimen dan kontrol adalah 0,86 . Hasil tersebut dibandingkan dengan $\mathrm{F}_{\text {tabel }}(\mathrm{dk}=5$, taraf signinfikasi 0,05) sebesar 5, 050 menunjukkan bahwa $F_{\text {hitung }}$ lebih kecil daripada $F_{\text {tabel }}(0,86<5,050)$. Hal ini berarti bahwa kelompok data pada kelas eksperimen dan kontrol dinyatakan homogen.

Selanjutnya diberikan perlakuan, yakni kelas eksperimen diajar dengan menggunakan model pembelajaran tebak kata sedangkan siswa pada kelas kontrol diajar tanpa menggunakan model pembelajaran tebak kata. Setelah 4 kali pertemuan kedua kelas tersebut kembali diberi tes yaitu post-test keterampilan berbicara bahasa 
Jerman, dari hasil post- test pada kelas eksperimen (XI IPS 2) yang diajar dengan menggunakan model pembelajaran tebak kata mengalami peningkatan nilai yang cukup signifikan. Hal ini dapat dilihat dengan perolehan nilai untuk kelas eksperimen, sebanyak 10 siswa (36\%) yang memeroleh nilai terendah yaitu 50 dan 1 siswa (36\%) yang memeroleh nilai tertinggi yaitu 75 dengan rata-rata 59,75 yang sebelumnya hanya $\mathbf{5 0 , 6 8}$. Siswa telah mampu menyampaikan informasi dengan kalimat yang baik, kosakata yang digunakan sudah memadai serta pelafalan dan intonasi yang baik.

Adapun kelas kontrol yang belajar tanpa menggunakan model pembelajaran tipe tebak kata tidak mengalami peningkatan nilai yang begitu signifikan, dengan perolehan nilai menunjukkan bahwa 10 siswa (36\%) yang memeroleh nilai terendah, yaitu 42 dan hanya 2 siswa (7\%) yang memeroleh nilai tertinggi, yaitu 75 dengan nilai rata-rata $\mathbf{5 1 , 2 8}$. Tidak seperti pada kelas eksperimen, informasi yang disampaikan masih terdapat kesalahan pada kalimat, kosakata yang digunakan cukup memadai serta terdapat beberapa kesalahan pada pelafalan dan intonasi tetapi tidak mempengaruhi pemahaman. Selanjutnya dilakukan pengujian hipotesis dengan menggunakan uji-t untuk mengetahui hasil akhir dari penelitian ini, yaitu ada tidaknya perbedaan tingkat keterampilan berbicara bahasa Jerman siswa pada hasil post-test kelas eksperimen dan kelas kontrol. Hasil penghitungan tersebut diperoleh data bahwa t-hitung sebesar 3,34. Setelah dibandingkan dengan t-tabel pada taraf signifikansi 5\% (0,05) dan dk 54 sebesar 2,005 maka dapat disimpulkan bahwa t-hitung lebih besar daripada t-tabel, yakni t-hitung $(3,34)>t$-tabel $(2,005)$. Dengan demikian, $\mathrm{H}_{1}$ yang menyatakan bahwa model pembelajaran kooperatif tipe tebak kata efektif dalam keterampilan berbicara bahasa Jerman siswa kelas XI SMA Semen Tonasa Kabupaten Pangkep dinyatakan diterima, dan $\mathrm{H}_{\mathrm{o}}$ yang menyatakan bahwa model pembelajaran kooperatif tipe tebak kata tidak efektif dalam keterampilan berbicara siswa kelas XI SMA Semen Tonasa Kabupaten Pangkep dinyatakan ditolak.

Hal tersebut didukung oleh teori yang dikemukakan oleh Suprijono dalam Kurniasari (2009:2) bahwa model pembelajaran kooperatif tipe tebak kata adalah suatu metode pembelajaran dengan cara menebak hal apa yang dimaksud di dalam indikator yang ada di karton. Sehingga dapat disimpulkan bahwa, $\mathrm{H}_{1}$ diterima maka penelitian tentang keefektifan model pembelajaran kooperatif tipe tebak kata dalam keterampilan berbicara bahasa Jerman siswa kelas XI SMA Semen Tonasa kabupaten pangkep, dinyatakan berhasil.

\section{KESIMPULAN}

Berdasarkan hasil analisis data yang telah dipaparkan pada bab sebelumnya, maka disimpulkan bahwa penggunaan model pembelajaran kooperatif tipe Tebak Kata efektif dalam keterampilan berbicara bahasa Jerman siswa kelas XI SMA Semen Tonasa Kabupaten Pangkep. Hal ini telah dibuktikan dari pengujian hipotesis dengan menggunakan uji-t pada nilai post-test siswa dengan nilai analisis data yaitu $\mathbf{t}_{\text {hitung }}=$ 3,34 $>\boldsymbol{t}_{\text {tabel }}=\mathbf{2 , 0 0 5}$ pada taraf signifikan 0,05. Karena $t_{\text {hitung }}$ lebih besar daripada $t_{\text {tabel }}$ maka hal tersebut menunjukkan bahwa penggunaan model pembelajaran kooperatif tipe Tebak Kata efektif dalam keterampilan berbicara bahasa Jerman siswa kelas XI SMA Semen Tonasa Kabupaten Pangkep. 


\section{DAFTAR PUSTAKA}

Djumingin, Sulastriningsih. 2011. Strategi dan Aplikasi Model Pembelajaran Inovatif Bahasa dan Sastra. Makassar: Badan Penerbit UNM.

Isjoni. 2014. Cooperative Learning Efektifitas Pembelajaran Kelompok. Bandung: Alfabeta.

Kurniasari,Nur dkk. 2009. Penggunaan Metode Tebak Kata Dan Media Kartu Kata Untuk Meningkatkan Pembelajaran Ips Pada Siswa Kelas lii Sdn Muktisari. Jurnal. PGSD FKIP Universitas Sebelas Maret.www.jurnal.fkip.uns.ac.id/index.php/pgsdkebumen/article/download/36 06/2525(Di akses pada tanggal 14 Februari 2018 Pukul 18.52).

Kurniasih, Imas dan Sani, Berlin. 2016. Ragam pengembangan model pembelajaran: Untuk Profesionalitas Guru. Jakarta: Kata Pena.

Rusman. 2014. Model-Model Pembelajaran Mengembangkan Profesionalisme Guru. Depok: PT Rajagrafindo Persada.

Suprijono, Agus. 2015. Cooperative Learning Teori dan Aplikasi PAIKEM. Yogyakarta: Pustaka Pelajar.

Syamsiyah,Nur dan Wedyawati, Nelly. 2017. Pengaruh Model Pembelajaran Kooperatif Tebak Kata Terhadap Hasil Belajar Siswa Pada Materi Pesawat Sederhana Kelas V. Jurnal.Vox Edukasi Vol 8 No.1.STKIP Persada Khatulistiwa Sintang.

http://jurnal.stkippersada.ac.id/index.php/voxedukasistkip/article/download/2 06/178.(Di akses pada tanggal 14 Februari 2018 Pukul 18.52).

Taniredja dkk. 2013. Model-Model Pembelajaran Inovatif Dan Efektif. Bandung: Alfabeta. 